\title{
If the British left: agricultural policy outside the CAP?
}

Article

Accepted Version

Swinbank, A. (2014) If the British left: agricultural policy outside the CAP? Eurochoices, 13 (2). pp. 36-39. ISSN 14780917 doi: https://doi.org/10.1111/1746-692X.12061 Available at https://centaur.reading.ac.uk/37419/

It is advisable to refer to the publisher's version if you intend to cite from the work. See Guidance on citing.

Published version at: http://onlinelibrary.wiley.com/doi/10.1111/euch.2014.13.issue-2/issuetoc

To link to this article DOI: http://dx.doi.org/10.1111/1746-692X.12061

Publisher: Wiley-Blackwell

All outputs in CentAUR are protected by Intellectual Property Rights law, including copyright law. Copyright and IPR is retained by the creators or other copyright holders. Terms and conditions for use of this material are defined in the End User Agreement.

\section{www.reading.ac.uk/centaur}

\section{CentAUR}

Central Archive at the University of Reading

Reading's research outputs online 


\title{
Point de Vue
}

\section{If the British left: Agricultural policy outside the CAP?}

\author{
Alan Swinbank
}

Revised April 2014

The United Kingdom's troubled relationship with the EU has entered new, uncharted, waters. Britain's Prime Minister, David Cameron, faced with major unease among the Conservative Party's MPs in the House of Commons, and amongst ordinary members of his party, has been forced to concede that - were the Conservatives to win an outright majority in the General Election due in 2015 - then he would seek to 'negotiate a new settlement with our European partners ... . And when we have negotiated that new settlement, we will give the British people a referendum with a very simple in or out choice. To stay in the EU on these new terms; or come out altogether' (Cameron, 2013). Opinion polls suggest that a narrow majority of the British public would - if asked today vote to leave. A recent poll of 1,662 likely voters suggested that 52 per cent could so vote, whilst 34 per cent were more likely to want to remain (see Figure 1), reflecting earlier polling results by the same group (Opinium Research, 2013)

Figure 1: Voting intentions, mid-January 2014 


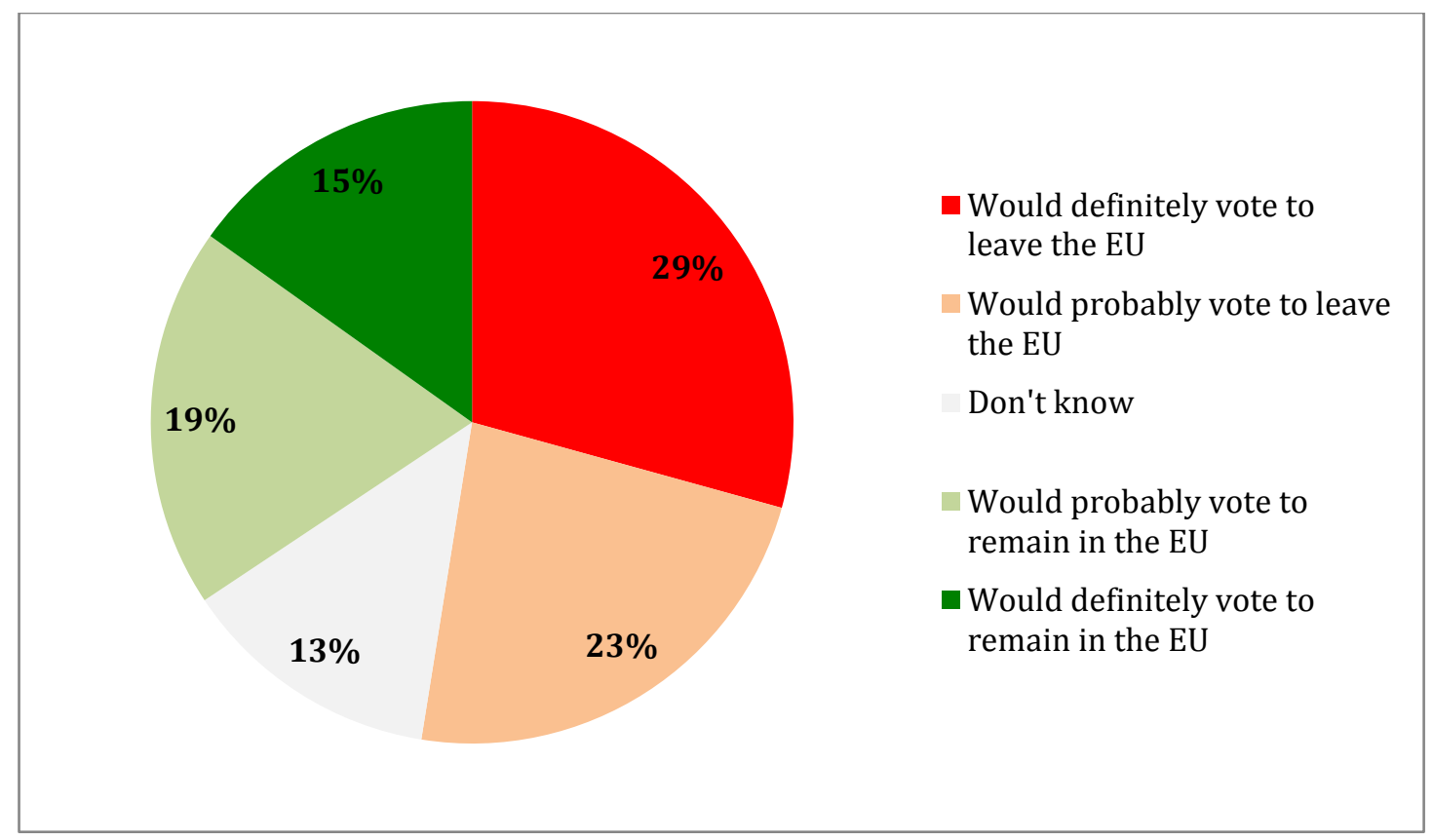

Response to the Question: If a referendum were held on the UK's membership of the European Union with the options being to remain a member or withdraw, how do you think you would vote? 14-16 January 2014. 1 per cent of the sample did not respond. Source: Opinium Research: http://news.opinium.co.uk/survey-results/political-polling-14th-january-2014, last accessed 7 February 2014.

It is not entirely clear (to this author at least) what the respondents thought their options were. What is the counter factual to continued membership of the EU? What are the feasible alternatives? It might be argued that the country faced a similar dilemma in June 1975 when Harold Wilson's Labour Government asked the public: 'Do you think that the United Kingdom should stay in the European Community (The Common Market)?'; and 17 million voted Yes whilst 8 million said No (Butler \& Kitzinger, 1996: 61, 1). But this was only the third year of membership and the full transition period had not been completed; GATT (General Agreement on Tariffs and Trade) rules were not particularly binding; and so it was not difficult to envisage a simple re-winding of arrangements, and a return to the previous status quo. The Anti-Marketeers' leaflet went further, however, suggesting that the UK, resuming its membership of the European Free Trade Association (EFTA), would be able to 'enjoy free entry for ... industrial exports into the Common Market without having to carry the burden of the Market's dear food policy or suffer rule from Brussels' (op. cit.: 304). 
Forty years on the situation is rather different. A return to a pre-1973 set of policies seems hardly feasible. World Trade Organization (WTO) rules are more exacting than the GATT provisions they updated in 1995. If the British public is to have the 'real choice between leaving or being part of a new settlement' that David Cameron has offered, then the alternatives will need spelling out - even if the Government ends up recommending continued membership, as Harold Wilson did in 1975. And if the British public were to vote No, the Government of the day would need to implement its alternative strategy (Plan B): the UK exiting the EU (or possibly a rump-UK, should Scotland vote for independence in September 2014).

We do not yet know what the euro-sceptics want to renegotiate, but the budget, migration from other EU states, and social legislation, loom large amongst their complaints. Whether the Common Agricultural Policy (CAP) will appear on the list, as it did in 1975, remains to be seen.

But if the UK were to exit the EU, what would British agricultural policy look like? What would replace the CAP? As the past president of the National Farmers' Union recently remarked, 'there has been no serious attempt to explain what an independent British agricultural policy would look like' (Kendall, 2013).

\section{Greener, and reduced, support?}

One possibility would be to swap EU legislation on market price support, direct payments with their cross compliance and greening provisions, and the rural development measures, with British legislation having exactly the same effect. But is that a likely outcome?

Successive British governments have repeatedly argued for more radical reform of the CAP than the EU has been willing to accept. For example, in June 2011, as the debate over the shape of the post-2013 CAP got underway, the UK Government (2011: 5) said:

'We believe there should be a very substantial cut to the CAP budget ..., concentrated on Pillar 1's direct payments. Future EU expenditure must be prioritised wisely to ensure that we are properly preparing for the long-term, 
providing best value for taxpayers money. For example, expenditure in a significantly smaller CAP should be targeted at the key objectives of encouraging a competitive, sustainable EU agriculture sector, helping to reduce farmer reliance on subsidies and preparing them for a very different future. In future, CAP expenditure should be increasingly focused on the provision of environmental public goods. Pillar 2 should therefore represent a greater share of a smaller CAP budget.'

To what extent these aspirations would translate into a reduction of support to British farmers, and a greater emphasis on the provision of environmental public goods, should the UK exit the EU is open to question. For the farming community the political acceptability of reduced Pillar 1 payments would depend in part upon the trade regime in place. In particular, if borders with the EU remained open, British farmers might bitterly complain that they faced an uneven playing field as their competitors were better able to remain in business as a result of more generous Pillar 1 payments subsidising their farming activities.

\section{Trade Policy?}

It seems likely that the UK, as a member of the WTO in its own right, would simply adopt the EU's most-favoured-nation ( $\mathrm{mfn}$ ) tariff barriers, and its trade regime for the least-developed countries (LDCs). Unilaterally it could then reduce its $\mathrm{mfn}$ tariffs if it wished. More problematic would be the web of regional trade agreements (RTAs) that the EU has with many non-LDCs around the world. Unless the UK had negotiated new RTAs with these countries, I do not see how the UK could continue with the EU's tariff preferences. Brazil would surely protest if the UK offered tariff concessions on raw sugar as if it were still applying the EU's Economic Partnership Agreements for example. Nor would the UK be party to the Transatlantic Trade and Investment Partnership currently being negotiated with the USA. 
WTO rules also imply that an independent UK would have to apply its $\mathrm{mfn}$ trade regime to its erstwhile partners in the EU - including, potentially, an independent Scotland - unless it had already negotiated with them a valid RTA. Would this be the Government's Plan B; and would the rest of the EU be willing to enter into such an agreement if it did not include all of the four 'freedoms' of movement of goods, capital, services, and persons? This, after all, is the basic premise of the European Economic Area (EEA) covering three EFTA States and the EU (EFTA, 2014). Moreover, in order for this new trading arrangement to be offered as an option to the British public at the referendum, it would need to be negotiated in parallel with the Government's renegotiation of the terms of membership.

\section{The CAP?}

It is not only the UK that would need to adjust. In addition to the trade issues touched on above - Irish beef facing the same trade barriers as Brazilian beef in the British market for example - a British withdrawal could for example trigger a funding crisis in the EU. In 2012 Britain's net contribution to the EU budget after allowing for the British rebate - was €9.2 billion. This was equivalent to 17 per cent of expenditure in the other Member States on Budget Heading 2 (Natural Resources: which is predominantly the CAP) (European Commission, 2013: Annex 2c). A budget shortfall of this magnitude would be unprecedented, and there is little to suggest how the EU would react. One possibility, in line with past practice, would be to protect the CAP's budget for direct payments whilst either slashing expenditure elsewhere or raising Member State contributions.

\section{Unintended consequences}

The outcome of the 2015 General Election is by no means certain. A renegotiation of the terms of membership might result in radical changes that would assuage much of the euro-scepticism currently pervading British public opinion. Faced with an in-out vote the British public might well decide they prefer the status quo, as they did in 1975. But if they really are to choose in an in- 
out referendum then they need to know what the possible alternatives are. Moreover it is only when feasible alternatives have been set out that analysts and modellers can assess the likely consequences, and that competing claims can be rationally debated.

But it is not enough to suggest what the alternatives might be. A Government that rashly promises renegotiation and an in-out referendum really has to have Plan B in place should the public decide they want to quit. And the only way the Government can be sure Plan B is available is to embark upon twin negotiations for alternative settlements: a reconfigured EU, and the UK's exit. Even so, Plan A is not problem free. If politicians can avoid holding the promised referendum, or if an In vote can be secured, will that turn euro-sceptic Brits into enthusiastic EU citizens? I doubt it: but then that is true of some other EU states as well! And I suspect that the CAP would continue to be a source of controversy.

\section{Further Reading}

Butler, David \& Uwe Kitzinger (1996), The 1975 Referendum, Second Edition (Macmillan: Houndsmill).

Cameron, David (2013), EU speech at Bloomberg, Wednesday 23 January 2013, as written: http://www.number10.gov.uk/news/eu-speech-at-bloomberg/, last accessed 24 January 2013.

European Commission (2013), EU budget 2012 Financial Report (Publications Office of the European Union: Luxembourg).

European Free Trade Association (2014), The Basic Features of the EEA Agreement at http://www.efta.int/eea/eea-agreement/eea-basic-features , last accessed 13 February 2014.

Kendall, Peter (2013), The Case for British Agriculture in The UK \& Europe: Costs, Benefits, Options, The Regent's Report 2013 (Regent's University: London).

Opinium Research (2013), In or Out? Britain's Future in Europe (Opinium Research: London).

UK Government (2011), The Common Agricultural Policy after 2013: Government response to the Committee's Fifth Report of Session 2010-11, House of Commons Environment, Food and Rural Affairs Committee, Fifth Special Report of Session 2010-12, HC 1356 (The Stationery Office: London). 
Alan Swinbank is Emeritus Professor of Agricultural Economics at the University of Reading, UK. Email: $\underline{\text { A.Swinbank@reading.ac.uk }}$

Summary: If the Conservative party wins Britain's General Election in 2015 the incoming Government intends to negotiate a new settlement with the EU, and then hold an in-out referendum. Opinion polls suggest a narrow majority would vote to leave. To exercise an informed choice the electorate would need to know what feasible alternatives are available, so that these can be assessed and debated. Furthermore, in the event of a no vote the Government must be ready to implement its alternative strategy: Plan B. This implies that both a new EU settlement, and Plan B, need to be negotiated concurrently. There has been no serious attempt to explain what Plan B would mean for UK farm policy. Would, for example, British farmers continue to receive the level of support that they currently enjoy; would support be more focussed on environmental objectives? WTO rules on most-favoured-nation treatment and regional trade agreements would apply. Could a WTO compatible agri-food trade agreement be negotiated with its former EU partners, or would Irish and Brazilian beef face the same tariff barriers on imports into the British market? For the EU, the loss of a major net contributor to EU finances could result in a re-examination of the CAP budget.

Pullquote: "If the British public is to have a 'real choice between leaving or being part of a new settlement', then the alternatives will need spelling out" 